\title{
Gray-Scale and Color Doppler US Features Corresponding to Histological Subtypes of Papillary Thyroid Carcinoma ${ }^{1}$
}

\author{
Sang Kwon Lee, M.D., Sun Young Kwon, M.D. ${ }^{2}$, SeongKu Woo, M.D.
}

Purpose: To compare the gray-scale and color or power Doppler ultrasonographic (US) features according to the histological subtypes of a papillary thyroid carcinoma (PTC).

Materials and Methods: The gray-scale and color or power Doppler US features of 159 surgically confirmed PTC (classic type of PTC, 69; classic type of papillary microcarcinoma [PMC], 67; and follicular variant of PTC [FVPTC], 23) in 118 patients were analyzed retrospectively. The following US characteristics were evaluated: the type of vascularization, echogenicity, outline, ratio of anteroposterior/transverse (AP/T) diameters, as well as the presence or absence of halo signs, cystic changes, and microcalcification.

Results: The most common type of vascularization was penetrating or central $(75.4 \%)$ for the classic type of PTC, avascular $(56.7 \%)$ for PMC, and peripheral and central $(82.6 \%)$ for FVPTC. The echogenicity was most commonly hypoechoic $(47.8 \%)$ for the classic type, hypoechoic $(74.6 \%)$ for PMC, and isoechoic (30.4\%) for FVPTC. The outline was most often irregular $(60.9 \%)$ for the classic type, irregular $(86.6 \%)$ for PMC, and regular $(91.3 \%)$ for FVPTC. The ratio of the AP/T diameters was 1.0 or more in $31.9 \%, 55.2 \%$, and $13.0 \%$, a halo sign was observed in $30.4 \%, 6.0 \%$, and $78.3 \%$, cystic changes was present in $1.4 \%, 0 \%$, and $21.7 \%$, and microcalcifications were present in $55.1 \%, 28.4 \%$, and $13.0 \%$ of those with the classic type, PMC, and FVPTC, respectively. Conclusion: The gray-scale and color Doppler US features corresponding to the histological subtypes of PTC are significantly different from one another. The US features of FVPTC appear to be significantly different from the other subtypes in that they tend to have more benign US characteristics than those of the classic type or PMC.

Index words : Thyroid, neoplasms

Thyroid, US

Ultrasound (US), Doppler studies

${ }^{1}$ Department of Radiology, Dongsan Medical Center, Keimyung University College of Medicine

${ }^{2}$ Department of Pathology, Dongsan Medical Center, Keimyung University College of Medicine

Received July 2, 2006 ; Accepted October 11, 2006

Address reprint requests to : Sang Kwon Lee, M.D., Department of Diagnostic Radiology, Dongsan Medical Center, Keimyung University College of

Medicine, 194 Dongsan-dong, Jung-gu, Daegu 700-712, Korea

Tel. 82-53-250-7735 Fax. 82-53-250-7766 E-mail: sklee@dsmc.or.kr 
It has been estimated that $40 \%$ to $50 \%$ of the asymptomatic population will have a thyroid nodule that is found incidentally on ultrasonography (US). However, the overall likelihood that a given thyroid nodule is malignant is approximately $5 \%$ to $6.5 \%$ (1-3). Many reports have been concerned with differentiating benign from malignant lesions of the thyroid gland without considering the histological types of thyroid carcinoma 14 , 5). The imaging features of follicular neoplasms, i.e. follicular adenoma and follicular carcinoma, may be different from those of the classic type of PTC in that they frequently have a regular outline (6). In addition, the US features associated with an increased risk of thyroid cancer, including the presence of calcification, marked hypoechogenicity, irregular outline, and an absence of halo (7), are frequently absent in follicular neoplasms. Therefore, before attempting to differentiate between benign and malignant thyroid lesions, it is appropriate to classify thyroid tumors into two architectural patterns, i.e., papillary and follicular. The imaging findings of the subtypes of PTC also may differ significantly from one another. However, to the best of our knowledge, there are few reports on the US features corresponding to the histological subtypes of PTC (8).

This study compared the characteristic gray-scale and color or power Doppler US features according to the subtypes of PTC i.e. classic type of PTC, classic type of papillary microcarcinoma (PMC), and FVPTC.

\section{Materials and Methods}

\section{Patients}

This retrospective study included 159 surgically confirmed PTC (classic type, 69; PMC, 67; and FVPTC, 23) in 118 patients (108 women and 10 men, age ranging from 20 to 75 years with a mean age of 45.2 years), who underwent a US examination at our hospital between January 2003 and November 2005. A small PTC measuring $10 \mathrm{~mm}$ or less in the maximal diameter was defined as a papillary microcarcinoma according to the World Health Organization (WHO) classification (9). All the patients provided written, informed consent, and approval was obtained from the Institutional Review Board to carry out this retrospective study.

\section{US Examinations and Interpretation}

Two investigators (SKL, SW) performed the gray-scale and color or power Doppler US examinations on all patients using a high-resolution real-time scanner (either
Sequoia 512, Acuson, Mountain View, CA, USA; or HDI-5000, Philips Medical system, Bothell, WA) equipped with a commercially available 8- $15 \mathrm{MHz}$ (Sequoia) or 5- 12MHz (HDI-5000) linear array transducer with color and power Doppler capability. The following US characteristics were evaluated: the type of vascularization on the color or power Doppler US, echogenicity, outline, the ratio of the anteroposterior/transverse $(\mathrm{AP} / \mathrm{T})$ diameters, and the presence or absence of halo sign, cystic change, and microcalcifications.

The type of vascularization in all lesions was evaluated during the color or power Doppler US examination. Doppler amplification was controlled so that the normal thyroid tissue did not show any noise. Four types of vascularization were identified: type I, absence of flow signals; type II, presence of peripheral vascularization; type III, presence of peripheral and central vascularization; and type IV, presence of penetrating or central vascularization. Type IV vascularization was defined as one or more central or penetrating color signals without any peripheral circular vascularity.

The echogenicity of the nodule, which was assessed with respect to the normal parenchyma of the thyroid gland and strap muscle, was classified as markedly hypoechoic (more hypoechoic compared with the strap muscle), hypoechoic (more hypoechoic compared with the normal thyroid parenchyma, but more hyperechoic than the strap muscle), isoechoic (isoechoic compared with the normal thyroid parenchyma), hyperechoic (more hyperechoic than the normal thyroid parenchyma), or mixed (a nodule containing both hypo- and hyperechoic areas). The outline of the nodule was assessed with respect to the smoothness and definability of the nodule, and was classified as regular, irregular, or lobular. The halo sign was defined as an anechoic or hypoechoic peripheral rim surrounding the nodule. Microcalcifications were defined as tiny echogenic spots with or without the acoustic shadows.

Two radiologists (SKL and SW), who were blinded to the patients' diagnosis, interpreted the gray-scale and color or power Doppler US images. The final diagnosis was reached by consensus.

The relationship between the qualitative variables, i.e., type of vascularization on color or power Doppler US, echogenicity, outline, ratio of AP/T diameters, and presence or absence of halo sign, cystic change, and microcalcifications, and subtypes of PTC (classic type of PTC versus PMC) was assessed using a chi-square test. 
The relationship between the same qualitative variable and the subtypes of PTC (classic type of PTC and PMC versus FVPTC) was assessed using a Fisher exact test.

\section{Results}

The long diameter of the lesions ranged from $10.4 \mathrm{~mm}$ to $60.4 \mathrm{~mm}$ (mean: $19.7 \mathrm{~mm}$ ) for the classic type of PTC, from $2.0 \mathrm{~mm}$ to $10.0 \mathrm{~mm}$ (mean: $6.6 \mathrm{~mm}$ ) for $\mathrm{PMC}_{\text {, and }}$ from $4.1 \mathrm{~mm}$ to $54.5 \mathrm{~mm}$ (mean: $21.8 \mathrm{~mm}$ ) for FVPTC. The most common type of vascularization on color or power Doppler US was type IV, I and II in the classic type (Fig. 1), PMC (Fig. 2), and FVPTC (Fig. 3), respectively (Table 1). With regard to vascularization of the lesions, type I was significantly more common in PMC ( $p$
$<.0001)$ than in the other two subtypes, type III in FVPTC $(p<.000001)$, and type IV in classic type of PTC $(p \leq .0001)$. Table 2 shows the echogenicity of the individual subtypes of PTC. The echogenicity was most commonly hypoechoic in the classic type and PMC (Figs. 1, 2), and isoechoic in FVPTC (Fig. 3) (Table 2).

Table 1. Types of Vascularization of the Subtypes of PTC

\begin{tabular}{llll}
\hline & $\begin{array}{l}\text { Classic Type } \\
(n=69)\end{array}$ & $\begin{array}{l}\text { PMC } \\
(n=67)\end{array}$ & $\begin{array}{l}\text { FVPTC } \\
(n=23)\end{array}$ \\
\hline Type I & $15(21.7 \%)$ & $38(56.7 \%)^{*}$ & $2(8.7 \%)$ \\
Type II & - & - & $2(8.7 \%)$ \\
Type III & $2(2.9 \%)$ & $2(3.0 \%)$ & $19(82.6 \%)^{*}$ \\
Type IV & $52(75.4 \%)^{*}$ & $27(40.3 \%)^{+}$ & - \\
\hline
\end{tabular}

* Significantly frequent than other two subtypes

+ Significantly frequent than one of other subtypes
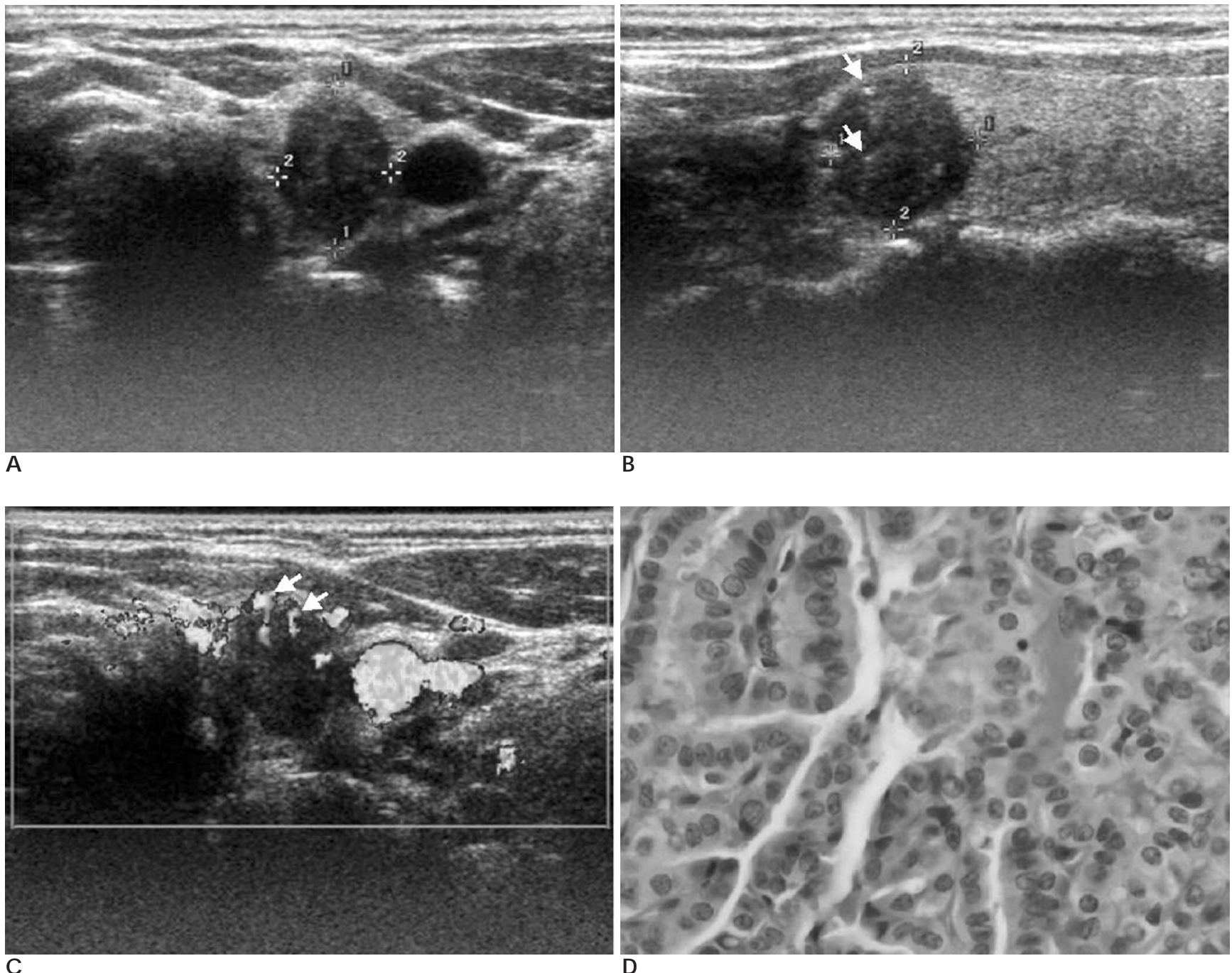

Fig. 1. A 44-year-old woman with the classic type of papillary thyroid carcinoma (PTC)

Transverse (A) and longitudinal (B) gray-scale ultrasonographic (US) images show an irregular hypoechoic solid mass (delineated by electronic calipers), more elliptical in shape, with microcalcifiations (arrows) in the left thyroid lobe. Transverse color Doppler US image (C) demonstrates penetrating vessels (arrows) within the mass. Histologically (D), the tumor cells show markedly pleomorphic nuclei with a ground-glass appearance, intranuclear pseudoinclusions and grooves $(\mathrm{H} \& \mathrm{E}, \times 600)$. 
With regard to the echogenicity of the nodules, hypoechogenicity was more frequent in PMC than in the other two subtypes $(p<.003)$, and iso- $(p<.000034)$ and hyperechogenicity $(p<.0151)$ was more common in FVPTC. The outline was most frequently irregular in the classic type and PMC (Figs. 1, 2), and regular in FVPTC (Fig. 3) (Table 3). With respect to the outline of

Table 2 Echogenicity of the Subtypes of PTC

\begin{tabular}{llll}
\hline & $\begin{array}{l}\text { Classic Type } \\
(n=69)\end{array}$ & $\begin{array}{l}\text { PMC } \\
(n=67)\end{array}$ & $\begin{array}{l}\text { FVPTC } \\
(n=23)\end{array}$ \\
\hline Markedly & $33(47.8 \%)$ & 50 & $6(26.1 \%)$ \\
hypoechoic & $25(36.2 \%)^{\dagger}$ & $(74.6 \%)^{*}$ & $6(26.1 \%)$ \\
Hypoechoic & - & 13 & $7(30.4 \%)^{*}$ \\
Isoechoic & - & $(19.4 \%)$ & $3(13.0 \%)^{*}$ \\
Hyperechoic & $11(16.0 \%)$ & - & $1(4.4 \%)$ \\
Mixed & - & - & - \\
Calcifications & & $1(1.5 \%)$ & \\
only & & $3(4.5 \%)$ & \\
\hline
\end{tabular}

* Significantly frequent than other two subtypes

+ Significantly frequent than one of other subtypes

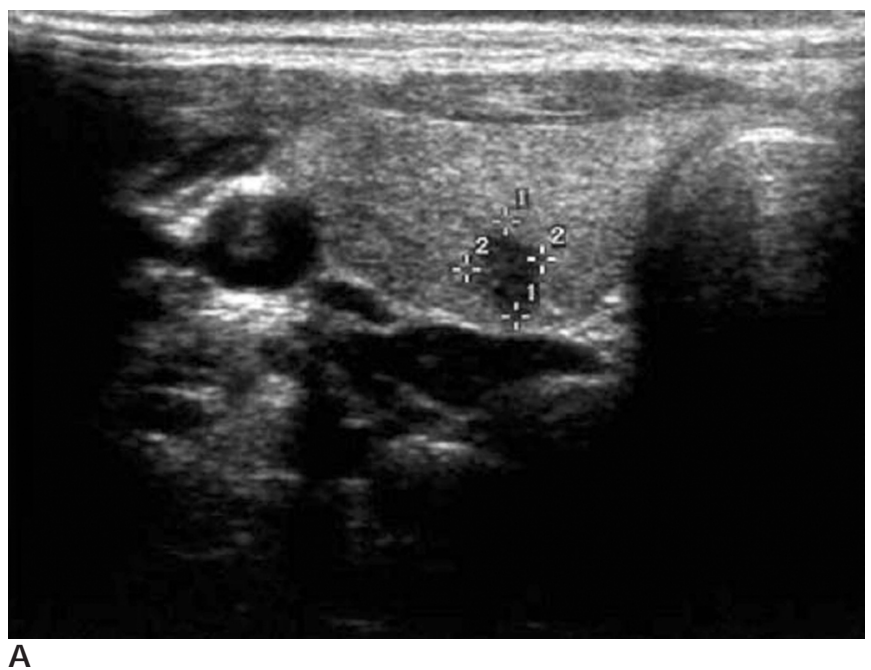

$\mathbf{A}$

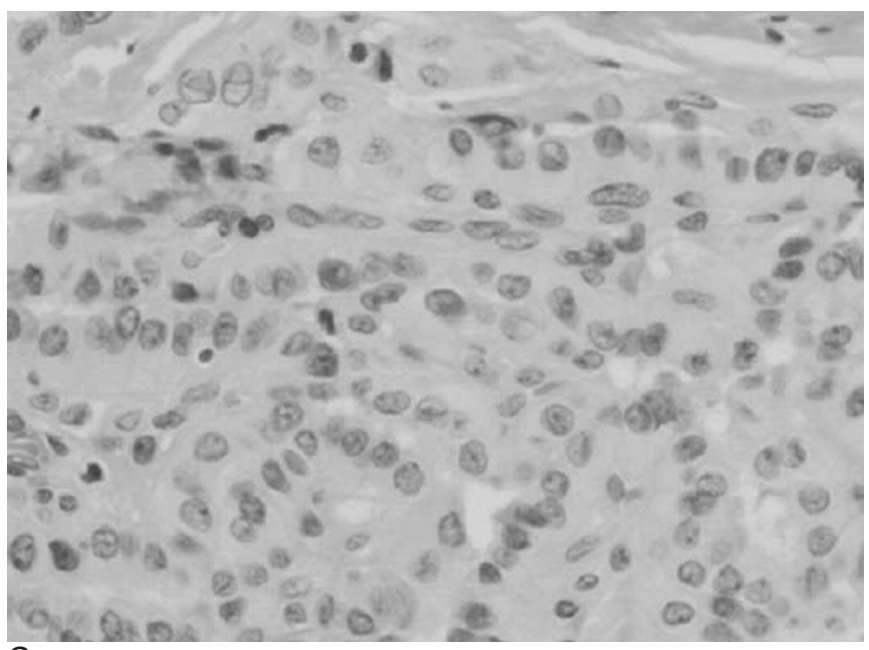

the lesions, PMC was more frequently irregular than in the classic type of PTC $(p=0.0014)$ or FVPTC $(p<$ .000001), and FVPTC was more often regular than either the classic type or PMC $(p<.000001)$. The ratio of the AP/T diameters was 1.0 or more in 22/69 (31.9\%) of the classic type (Fig. 1), 37/67 (55.2\%) of the PMC (Fig. $2)$, and $3 / 23(13.0 \%)$ of the FVPTC. Halo sign was present in 21/69 (30.4\%) of the classic type, $4 / 67$ (6.0\%) of the PMC, and 18/23 (78.3\%) of the FVPTC (Fig. 3). Cystic changes were noted in $1 / 69(1.4 \%), 0 \%$, and $5 / 23$ $(21.7 \%)$ of the classic type, PMC, and FVPTC (Fig. 3), re-

Table 3. Outline of the Subtypes of PTC

\begin{tabular}{llll}
\hline & $\begin{array}{l}\text { Classic Type } \\
(n=69)\end{array}$ & $\begin{array}{l}\text { PMC } \\
(n=67)\end{array}$ & $\begin{array}{l}\text { FVPTC } \\
(n=23)\end{array}$ \\
\hline Irregular & $42(60.9 \%)^{\dagger}$ & $58(86.6 \%)^{*}$ & - \\
Regular & $10(14.5 \%)$ & $8(11.9 \%)$ & $21(91.3 \%)^{*}$ \\
Lobular & $17(24.6 \%)$ & & $2(8.7 \%)$ \\
\hline
\end{tabular}

* Significantly frequent than other two subtypes

+ Significantly frequent than one of other subtypes

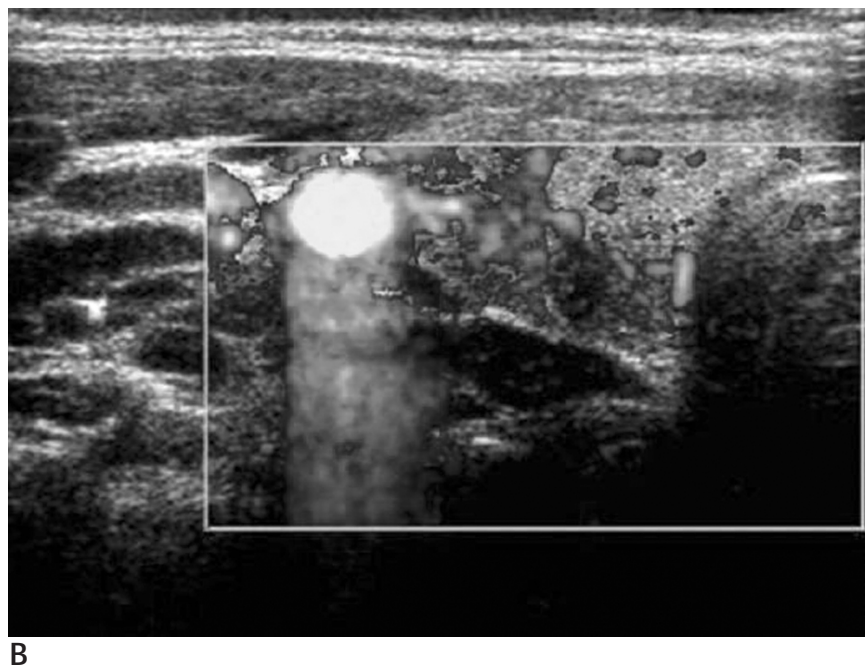

Fig. 2 A 38-year-old woman with classic type of papillary microcarcinoma (PMC)

Transverse gray-scale ultrasonographic (US) image (A) reveals an irregular markedly hypoechoic solid nodule (delineated by electronic calipers), more elliptical in shape, in the right thyroid lobe. Transverse power Doppler US image (B) shows no color signals within the nodule. Histologically $(\mathbf{C})$, the tumor cells demonstrate prominent pleomorphism with ground-glass appearing nuclei, and intranuclear pseudoinclusions and grooves $(\mathrm{H} \& \mathrm{E}, \times 600)$ 

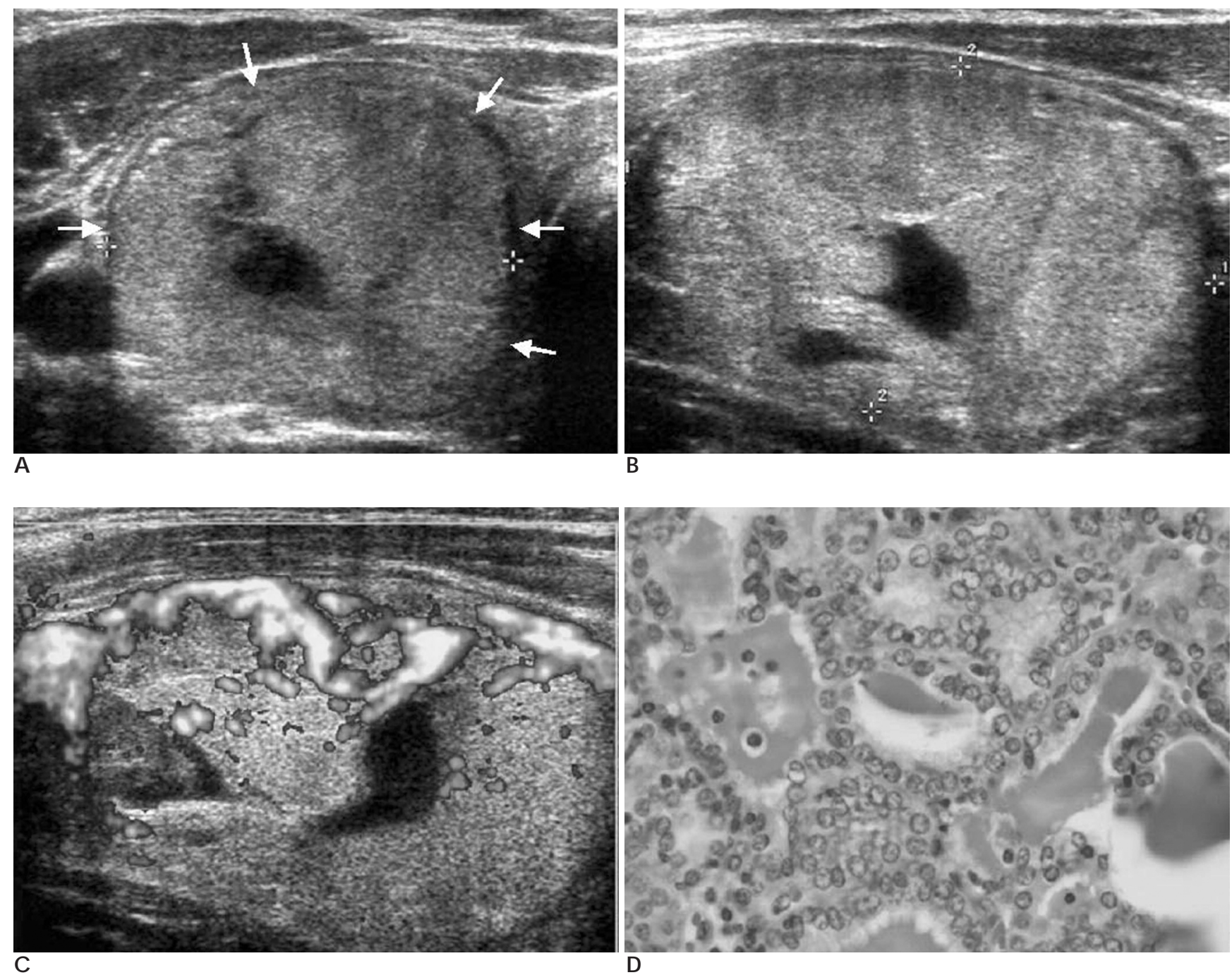

Fig. 3. A 53-year-old man with follicular variant of papillary thyroid carcinoma (FVPTC) Transverse (A) and Longitudinal (B) grayscale ultrasonographic (US) images show a large well demarcated isoechoic solid mass (delineated by electronic calipers) with cystic changes and a peripheral sonolucent halo (arrows in A) in the right thyroid lobe. Longitudinal power Doppler US image (C) reveals peripheral and central color signals. Microscopic finding (D) of tumor mass demonstrates atypical follicular cells forming follicles. The nuclei of the tumor cells shows a ground-glass appearance with intranuclear pseudoinclusions and grooves $(\mathrm{H} \& \mathrm{E}, \times$ 400).

spectively. Microcalcifications were present in 38/69 $(55.1 \%)$ of the classic type (Fig. 1), 19/67 (28.4\%) of the PMC, and 3/23 (13.0\%) of the FVPTC. A lesion was more elliptical in shape was identified more frequently in the PMC than in the classic type $(p=.0101)$ or FVPTC $(p=.000505)$. Halo signs were found more often in FVPTC than in the classic type $(p=.000078)$ or PMC $(p<$ $.000001)$, and more frequently in the classic type than in PMC ( $p=.0005)$. Cystic changes were more common in FVPTC than in the classic type $(p=.003398)$ or PMC $(p=.000766)$, and there were more microcalcifications in the classic type than in PMC $(p=0.0029)$ or FVPTC $(p=$ .000522).

\section{Discussion}

Papillary thyroid carcinoma is the most common histological type of thyroid cancer, accounting for $85 \%$ of cases $(10,11)$. Interestingly, the overall incidence of PTC has increased over the past several decades. With the increasing use of high-resolution US and fine-needle aspiration cytology (FNAC), thyroid nodules that are too small to be palpated are being discovered more often (12). The classic type of PTC is the most common form of PTC. According to the World Health Organization (WHO), a papillary microcarcinoma is defined as a small PTC with the maximal diameter measuring 10 
$\mathrm{mm}$ or less (9). An autopsy series showed that papillary microcarcinomas have a prevalence ranging from 5.6\% to $35.6 \%$ depending on the meticulousness of the examination and the diagnostic criteria (13- 15). Although most patients with PMC have a benign clinical course, PMC with an invasive course has also been demonstrated (16). The FVPTC is the second most common subtype of PTC after classic PTC, accounting for $10 \%$ to $15 \%$ of all cases (17). It is defined by a follicular architecture with the nuclear features of classic PTC. Although it has been suggested that FVPTC may behave differently from a normal papillary thyroid carcinoma (18), a large series has shown that the pattern of behavior of FVPTC and the usual papillary carcinoma are similar, except for a tendency toward more extracervical metastases in FVPTC (19).

The primary goal of US in an evaluation of focal thyroid lesion was to determine which thyroid lesions are malignant and therefore warrant FNA (20). Several US characteristics have been examined as potential predictors of a thyroid malignancy, including the presence of microcalcifications, an irregular outline, marked hypoechogenicity, the absence of halo signs, a more elliptical shape, increased intranodular vascularization, and a predominantly solid composition $(2-4,21)$. However, as already reported by Chan et al. (2), there is a broad spectrum of sonographic findings in PTC. Half of the PTC in their series had at least one uncommon sonographic feature.

In this study, the PMC was regarded as a separate entity from the classic type of PTC in determinin if there were any differences between gray-scale and color or power Doppler US features according to the size of the classic type of PTC. Interestingly, with regard to the type of vascularization, echogenicity, outline, ratio of the $\mathrm{AP} / \mathrm{T}$ diameters, the presence of halo signs and microcalcifications, there were statistically significant differences between the classic type of PTC and PMC, i.e., PMC was more often avascular, hypoechoic, and more likely to have an irregular outline than the classic type. In contrast, the halo sign and microcalcifications were found more commonly in the classic type of PTC. These results were somewhat unexpected, and similar results have not been reported in the English literature.

The role of color or power Doppler US in evaluating thyroid nodules for a malignancy is unclear. Recently, Lebkowska et al. (22) examined thyroid nodules using power Doppler US and an immunohistochemical reaction. The increased flow pattern in the center nodules on power Doppler US correlated with the proliferative activity, and consequently with a malignancy. Holden (23) observed different types of vascularization in benign nodules and carcinomas, in that the carcinomas had a greater degree internal vascularization. In contrast, Shimamoto et al. (24) reported that there was no correlation between the extent ant type of vascularization and the nature of the nodules. Vascular endothelial growth factor (VEGF) is present in the epithelial cells of normal thyroid gland, Graves' disease, thyroiditis, and thyroid tumors. Increased VEGF is demonstrable in thyroid cancers in contrast to the normal gland or benign tumors (25). Similarly, the microvascular density of the tumors is higher in malignant tumors than in benign tumors (26). There is a good correlation between the circulating VEGF levels and the intrathyroidal vascular area assessed by color flow Doppler ultrasonography (27). Interestingly, a papillary microcarcinoma does not show higher VEGF expression than the normal thyroid gland (25). This may indicate an absence of color signals in many cases $(56.7 \%)$ of PMC and in some cases $(21.7 \%)$ of the classic type of PTC. All the cases with the classic type of PTC that did not show color signals in the center of the nodule were $<15 \mathrm{~mm}$ in the long diameter. The frequent type IV vascularization of the classic type of PTC and PMC might be due to the frequent absence of complete encapsulation. Moreover, the common type III vascularization in FVPTC may be related to the common encapsulation in this type of PTC (28).

Although there are certain trends in the US observations of benign and malignant thyroid nodules, there is also some overlap in their appearance $(2,29)$. This may result when attempting to distinguish between benign and malignant lesions according to the above-mentioned criteria without considering the histological types of thyroid carcinoma. Therefore, before attempting to distinguish between benign and malignant lesions it is appropriate to classify the thyroid tumor into two growth patterns, i.e., papillary and follicular. This is because many follicular neoplasms, i.e., follicular adenoma, follicular carcinoma, and FVPTC, may be categorized as benign lesion when using above-mentioned US characteristics even though they are malignant. Hence, different diagnostic criteria should be applied for lesions suggestive of follicular neoplasms to distinguish between benign and malignant follicular lesions. Neither conventional US nor FNA yielded satisfactory results in the differentiation of benign and malignant follicular neoplasms of the thyroid (6). Some authors suggested that the vascular 
pattern and velocimetric parameters might be useful (30) but there is some controversy (24).

The US findings of the subtypes of papillary carcinoma also may differ significantly. However, to the best of our knowledge, there are no reports comparing the features of gray-scale with those of color or power Doppler US corresponding to the individual subtype of PTC. This study applied these US criteria of a thyroid malignancy to the individual histological subtype of PTC and found that FVPTC had many of the US features of benign tumors: (1) peripheral and central vascularization $(82.6 \%),(2)$ isoechoic internal echogenicity $(30.4 \%),(3)$ regular $(91.3 \%)$ or lobular $(8.7 \%)$ outline, (4) ratio of $\mathrm{AP} / \mathrm{T}$ diameters less than $1(87 \%),(5)$ frequently documented halo sign $(78.3 \%)$, (6) frequent cystic change $(21.7 \%)$, and (7) less frequent microcalcifications (13\%) compared with the other two subtypes. There are few reports of the US findings of FVPTC (8). Komatsu et al. (8) retrospectively examined the preoperative US diagnosis of six patients with FVPTC. According to their study, only one of the six cases was preoperatively diagnosed with a papillary carcinoma, the remainder were diagnosed with a follicular adenoma (four patients), and an adenomatous goiter (one case). It is believed that FVPTC significantly contributes to the overlap between benign and malignant US features. Therefore, in order to avoid a misdiagnosis, it is important to determine if the mass has a papillary or follicular growth pattern before attempting to evaluate the PTC.

In conclusion, there is a significant difference between the gray-scale and color Doppler US features corresponding to the histological subtypes of PTC. The US features of FVPTC are significantly different from the other subtypes in that they tend to have more benign US characteristics than those of the classic type or PMC.

\section{References}

1. Ezzat S, Sarti DA, Cain DR, Braunstein GD. Thyroid incidentalomas: prevalence by palpation and ultrasonography. Arch Intern Med 1994;154:1838-1840

2. Chan BK, Desser TS, McDougall IR, Weigel RJ, Jeffrey RB Jr. Common and uncommon sonographic features of papillary carcinoma. J Ultrasound Med 2003;22:1083-1090

3. Papini E, Guglielmi R, Bianchini A, Crescenzi A, Taccogna S, Nardi F, et al. Risk of malignancy in nonpalpable thyroid nodules: predictive value of ultrasound and color Doppler features. J Clin Endocrinol Metab 2002;87:1941-1946

4. Kim EK, Park CS, Chung WY, Oh KK, Kim DI, Lee JT, et al. New sonographic criteria for recommending fine-needle aspiration biopsy of nonpalpable solid nodules of the thyroid. AJR Am J Roentgenol 2002;178:687-691
5. Wienke JR, Chong WK, Fielding JR, Zou KH, Mittelstaedt CA. Sonographic features of benign thyroid nodules: interobserver reliability and overlap with malignancy. J Ultrasound Med 2003;22:1027-1031

6. Fukunari $N$, Nagahama $M$, Sugino $K$, Mimura $T$, Ito $K$, Ito $K$. Clinical evaluation of color Doppler imaging for the differential diagnosis of thyroid follicular lesions. World J Surg 2004;28:12611265

7. Frates MC, Benson CB, Charboneau JW, Cibas ES, Clark OH, Coleman BG, et al. Management of thyroid nodules detected at US: society of radiologists in ultrasound consensus conference statement. Radiology 2005;237:794-800

8. Komatsu M, Hanamura N, Tsuchiya S, Seki T, Kuroda T. Preoperative diagnosis of the follicular variant of papillary carcinoma of the thyroid: discrepancy between image and cytologic diagnoses. Radiat Med 1994;12:293-299

9. Hedinger C, Williams ED, Sobin LH. Histological typing of thyroid tumors. 2nd ed. Berlin: Springer-Verlag, 1988:1-18

10. DeGroot LJ, Kaplan EL, McCormick M, Straus FH. Natural history, treatment, and course of papillary thyroid carcinoma. J Clin Endocrinol Metab 1990;71:414-424

11. Schlumberger MJ. Papillary and follicular thyroid carcinoma. $N$ Engl J Med 1998; 338:297-306

12. Tan GH, Gharib H. Thyroid incidentalomas: management approaches to nonpalpable nodules discovered incidentally on thyroid imaging. Ann Intern Med 1997;126:226-231

13. Bisi H, Fernandes VS, de Camargo RY, Koch L, Abdo AH, de Brito T. The prevalence of unsuspected thyroid pathology in 300 sequential autopsies, with special reference to the incidental carcinoma. Cancer 1989;64:1888-1893

14. Yamamoto Y, Maeda T, Izumi K, Otsuka H. Occult papillary carcinoma of the thyroid. A study of 408 autopsy cases. Cancer 1990;65: 1173-1179

15. Harach HR, Franssila KO, Wasenius VM. Occult papillary carcinoma of the thyroid. A "normal" finding in Finland. A systematic autopsy study. Cancer 1985;56:531-538

16. Strate SM, Lee El, Childers JH. Occult papillary carcinoma of the thyroid with distant metastases. Cancer 1984;54:1093-1100

17. Chem KT, Rosai J. Follicular variant of thyroid papillary carcinoma: a clinicopathologic study of six cases. Am J Surg Pathol 1977;1:123-130

18. Zhu Z, Gandhi M, Nikiforova MN, Fischer AH, Nikiforov YE. Molecular profile and clinical-pathologic features of the follicular variant of papillary thyroid carcinoma. An unusually high prevalence of ras mutations. Am J Clin Pathol 2003;120:71-77

19. Tielens ET, Sherman SI, Hruban RH, Ladenson PW. Follicular variant of papillary thyroid carcinoma. A clinicopathologic study. Cancer 1994;73:424-431

20. Tessler FN, Tublin ME. Thyroid sonography: current applications and future directions. AJR Am J Roentgenol 1999;173:437-443

21. Lyshchik A, Drozd V, Demidchik Y, Reiners C. Diagnosis of thyroid cancer in children: value of gray-scale and power Doppler US. Radiology 2005;235:604-613

22. LEbkowska UM, Dzieciol J, Lemancewicz D, Boguslowicz W, Lewszuk A. The influence of the vascularisation of the follicular thyroid nodules on the proliferative activity of the follicular cells. Folia Morphol (Warsz) 2004;63:79-81

23. Holden A. The role of colour and duplex Doppler ultrasound in the assessment of thyroid nodules. Australas Radiol 1995;39:343349

24. Shimamoto K, Endo T, Ishigaki T, Sakuma S, Makino N. Thyroid nodules: evaluation with color Doppler ultrasonography. $J$ 


\section{Ultrasound Med 1993;12:673-678}

25. Bunone G, Vigneri P, Mariani L, Buto S, Collini P, Pilotti S, et al. Expression of angiogenesis stimulators and inhibitors in human thyroid tumors and correlation with clinical pathological features. Am J Pathol 1999;155:1967-1976

26. Segal K, Shpitzer T, Feinmesser M, Stern Y, Feinmesser R. Angiogenesis in follicular tumors of the thyroid. J Surg Oncol 1996; 63:95-98

27. Iitaka M, Miura S, Yamanaka K, Kawasaki S, Kitahama S, Kawakami $Y$, et al. Increased serum vascular endothelial growth factor levels and intrathyroidal vascular area in patients with
Graves' disease and Hashimoto's thyroiditis. J Clin Endocrinol Metab 1998;83:3908-3912

28. Albores-Saavedra J, Wu J. The many faces and mimics of papillary thyroid carcinoma. Endocr Pathol 2006;17:1-18

29. Propper RA, Skolnick ML, Weinstein BJ, Dekker A. The nonspecificity of the thyroid halo sign. J Clin Ultrasound 1980;8:129-132

30. Miyakawa M, Onoda N, Etoh M, Fukuda I, Takano K, Okamoto $\mathrm{T}$, et al. Diagnosis of thyroid follicular carcinoma by the vascular pattern and velocimetric parameters using high resolution pulsed and power Doppler ultrasonography. Endocr J 2005;52:207-212

\title{
유두상 갑상선 암종의 조직아형에 따른 회색조 및 색도플러 초음파 소견 ${ }^{1}$
}

\author{
${ }^{1}$ 계명대학교 의과대학 동산의료원 영상의학과학교실 \\ ${ }^{2}$ 계명대학교 의과대학 동산의료원 병리학교실
}

이상권. 권선영ㄹ. 우성구

목적: 유두상 갑상선 암종의 조직아형에 따른 회색조 및 색도플러 또는 강화도플러 초음파 소견을 비교하고자 하였다.

대상과 방법: 118 명의 환자에서 수술로서 확진된 159개의 유두상 갑상선 암종(classic type 69예, classic type of papillary microcarcinoma[PMC] 67예, follicular variant of papillary thy roid carcinoma[FVPTC], 23예)의 회색조 및 색도플러 또는 강화도플러 초음파 소견을 후향적으로 분석하였다. 초음파 소견은 병변의 혈관분포의 형태, 에코발생정도, 경계, 전*후경/횡경의 비, 달무리 징후, 낭성변화 및 미세석회화의 존재 유무를 중심으로 평 가하였다.

결과: 병소의 가장 흔한 혈관분포의 형태는 classic type에서는 투과성 또는 중심성 $75.4 \%)$ 이었고, PMC에서는 무혈관성 (56.7\%)이었으며, FVPT C에서는 말초성 및 중심성 (82.6\%)이었다. 에코발생정도는 classic type 및 PMC 에서 저명한 저에코가 각각 $47.8 \%$ 및 $74.6 \%$ 로 가장 흔하였고, FVPTC에서는 등에코(30.4\%)가 가장 많았다. 병소의 경계는 classic type과 PMC에서는 불규칙한 경우가 각각 $60.9 \%$ 및 $86.6 \%$ 로 가장 많았고, FVPT C에서 는 규칙적인 경우(91.3\%)가 가장 많았다. 전*후경/횡경의 비가 1.0 이상인 경우와 달무리 징후, 낭성변화 및 미 세석회화의 존재는 classic type에서 각각 $31.9 \%, 30.4 \%, 1.4 \%$ 및 $55.1 \%$ 에서 관찰되었으며, PMC에서는 각각 $55.2 \%, 6.0 \%, 0 \%$ 및 $28.4 \%$ 에서 관찰되었고, $\mathrm{FVPT}$ C에서는 각각 $13.0 \%, 78.3 \%, 21.7 \%$ 및 $13.0 \%$ 에서 관찰되 었다.

결론: 유두상 갑상선 암종의 조직아형에 따른 회색조 및 색도플러 또는 강화도플러 초음파소견은 서로 유의하게 차이가 있었으며, 특히 FVPTC는 classic type이나, PMC에 비해 양성질환의 초음파소견을 보인다는 점에서 다 른 조직아형과 차이가 있었다. 